\title{
Quantitative genetics and fitness: lessons from Drosophila
}

\author{
Derek A. Roff and \\ Timothy A. Mousseau
}

Department of Biology, 1205 Avenue Dr., Penfield, Montréal, Québec, Canada H3A 1 B1.

This paper examines patterns of heritability and genetic covariance between traits in the genus Drosophila. Traits are divided into the categories, morphology, behaviour, physiology and life history. Early theoretical analyses suggested that life history traits should have heritabilities that are lower than those in other categories. Variable pleiotrophy, environmental variation, mutation and niche variation may, however, maintain high heritabilities. In Drosophila the heritabilities of life history traits are lower than morphological or physiological traits but may exceed 20 per cent. The pattern of variation in the heritability of behavioural traits is similar to that of life history traits. Genetic covariance between morphological traits and between morphological and life history traits are all positive but those between life history traits have variable sign. Negative covariance between traits supports the variable pleiotropy hypothesis but other factors such as environmental heterogeneity, or mutation cannot be excluded.

\section{INTRODUCTION}

The quantitative genetic model developed by Fisher (1930) has, over the last two decades, been variously interpreted, modified and extended (O'Donald, 1967; Price, 1970; Slatkin, 1970; Bulmer, 1971; Cavalli-Sforza and Feldman, 1976, 1978; Emlen, 1980; Lande, 1982; Cheverud, 1984). Two principal components of these models are heritability and the genetic covariance matrix. Heritability, the additive component of polygenic variation, dictates, in large measure, the rate at which genetic change will occur, while the genetic covariance determines how traits will change in relation to each other. Early theoretical analyses of quantitative genetic variation suggested that traits associated directly with fitness, such as fecundity or viability, should have low heritabilities and positive covariation between traits (Fisher, 1930; Lerner, 1954; Robertson, A., 1955; Falconer, 1981). Although some evidence has been collated in support of this prediction, (see, for example, table 10.1 in Falconer 1981) the data are largely based on domestic, inbred animals and the collations are not very extensive. Furthermore, it has been suggested that genetic variation may remain high because of negative covariance between traits (Dickerson, 1955; Robertson, F., 1955; Rose, 1982,
1983; Rose and Charlesworth, 1981 b; Berven and Gill, 1983), environmental variation (Grant and Price, 1981; Rose, 1983), mutation (Dempster, 1955; Lande, 1975; Turelli, 1984) or niche variation (Van Valen', 1965).

The quantitative genetics of Drosophila have been extensively studied and in this paper we examine the variation in heritabilities with respect to different categories of traits, and the genetic and phenotypic correlations between traits, both within and between species. We address two questions: first, is there any pattern in the variation of heritabilities and genetic covariance of traits, and second, do traits directly associated with fitness have relatively low heritabilities?

\section{DEFINING THE DATA BASE}

For the purpose of this paper we define four categories of traits: (a) morphological traits; (b) behavioural traits; (c) physiological traits and (d) life history traits. Although all of these traits may fall within the purview of life history theory we have retained the term "life history trait" for traits such as fecundity, viability, survival and development rate, that are invariably and directly concerned with fitness. "Classical" theory predicts that 
life history traits will have lower heritabilities than traits in the other categories. It is certainly possible that certain traits in these other categories are under strong selection and, hence, have low heritabilities: it is for this reason that we compare heritabilities on a group basis and not by pairwise comparison of individual traits.

The data analysed in this paper are extensive but not exhaustive. A listing of the principal sources, divided according to trait, is given in an appendix. Only heritabilities in the narrow sense were accepted. Only six of the 130 studies computed heritabilities by the method of full sibs and these showed no consistent differences from the heritabilities estimated by some other method in the same study and were, therefore, retained.
Is it possible to predict the relative heritabilities of morphological, behavioural or physiological traits? Lee and Parsons (1968) suggest that behavioural traits will be "predominantly under stabilizing selection, but it may be premature to generalize". A priori it seems reasonable to suppose that behavioural traits, such as mating propensity, are more closely connected to fitness components than morphological traits. However, this assumption must be viewed with some caution as fecundity and development time in ectotherms are tightly correlated with body size, a morphological trait. These observations stress the unity of the phenotype and the lack of a strict hierarchical structure in traits. For this reason we do not make any predictions concerning the ranking of the

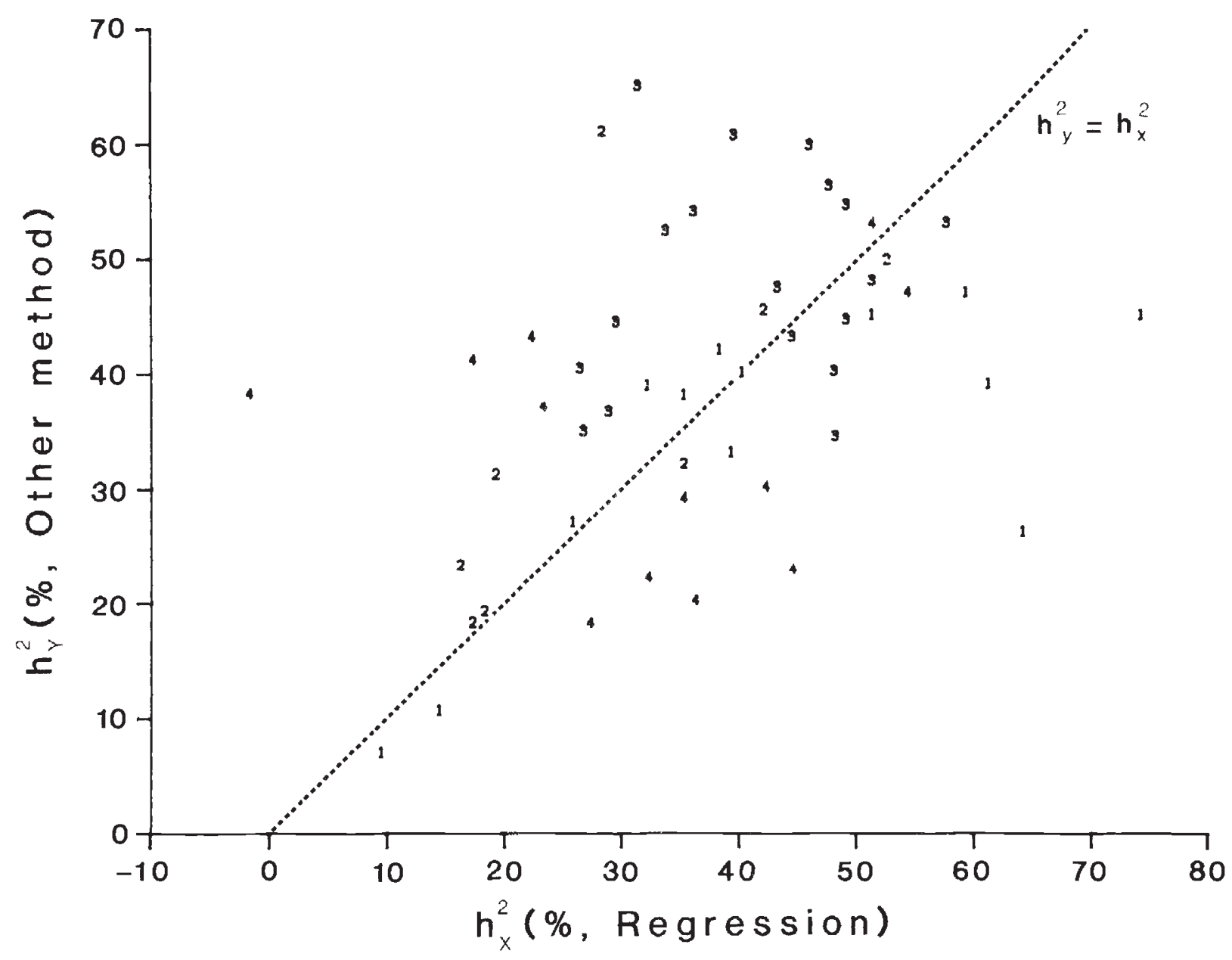

Figure 1 Scatter plot of $h^{2}$ estimated by selection (1), half sib (3), full sib (4) or miscellaneous inethods (2), $\left(h_{v}^{2}\right)$, on $h^{2}$ estimated from offspring on parent regression, $\left(h_{x}^{2}\right)$. Data from Beardmore et al. (1975), Clayton et al. (1957), Gallego and Lopez-Fanjul (1983), Lopez-Fanjul and Hill (1973 b), Mackay (1981), Reeve and Robertson (1953), Sheridan et al. (1968), Sorenson and Hill (1982, 1983), Tantawy (1956b), Tantawy et al. (1964), van Dijken and Scharloo (1979). 
heritabilities of morphology, behaviour and physiology, but rather use the data to discern whatever pattern might exist.

Most of the studies used wild, outbred strains of flies, though a few used inbred or synthetic strains (made by crossing several lines). The type of strain is indicated in the listing: the conclusions do not differ if only wild, outbred strains are analysed. The number of females used in founding these stocks varied from one to several hundred and the stocks were maintained under laboratory conditions prior to the estimation of heritability for one to many generations. We could find no effect of the size of the founding population or the duration of time within the laboratory and hence these variables will not be considered further.

The data base comprises heritabilities estimated by different methods and in many cases no standard errors are reported. To use these data we must establish: (a) that different methods estimate the same value or are not too biased; (b) that standard errors are small enough in those cases in which they have been calculated to suggest that estimates without standard errors are reliable.

For a wide variety of morphological characters and one behavioural trait, alternative estimates of heritability have been reported. These have been grouped into two categories, one being offspring on parent regression and the second, either selection, half sib ANOVA, full sib ANOVA, or "miscellaneous". There is a significant correlation between the $h^{2}$ estimated from offspring on parent regression $\left(h_{x}^{2}\right)$ and that estimated by some other method $\left(h_{y}^{2}\right)(r=0 \cdot 44, t=3 \cdot 42, P<0 \cdot 05, n=51$, fig. 1). Covariance analysis indicates that inclusion of the alternative method of analysis as a dummy variable significantly reduces the variance, with the slopes being homogeneous $\left(F_{3,43}=1 \cdot 86\right.$ for the slopes and $F_{1,46}=16.83$ for the effect of the alternative method). Since several studies constitute a large fraction of the data set it is possible that the effect is due to study rather than method.

Bias in different methods has also been found by Frankham et al. (1968) in their analysis of heritability of abdominal bristle number in $D$. melanogaster. Heritabilities were estimated by full sib and half sib analysis and realised heritabilities computed after 10 generations of selection. The realised heritability consistently underestimated those obtained by the other two methods, though there is statistically significant relationship between them $(r=0.51, n=27, t=2.97, P<0.01$,

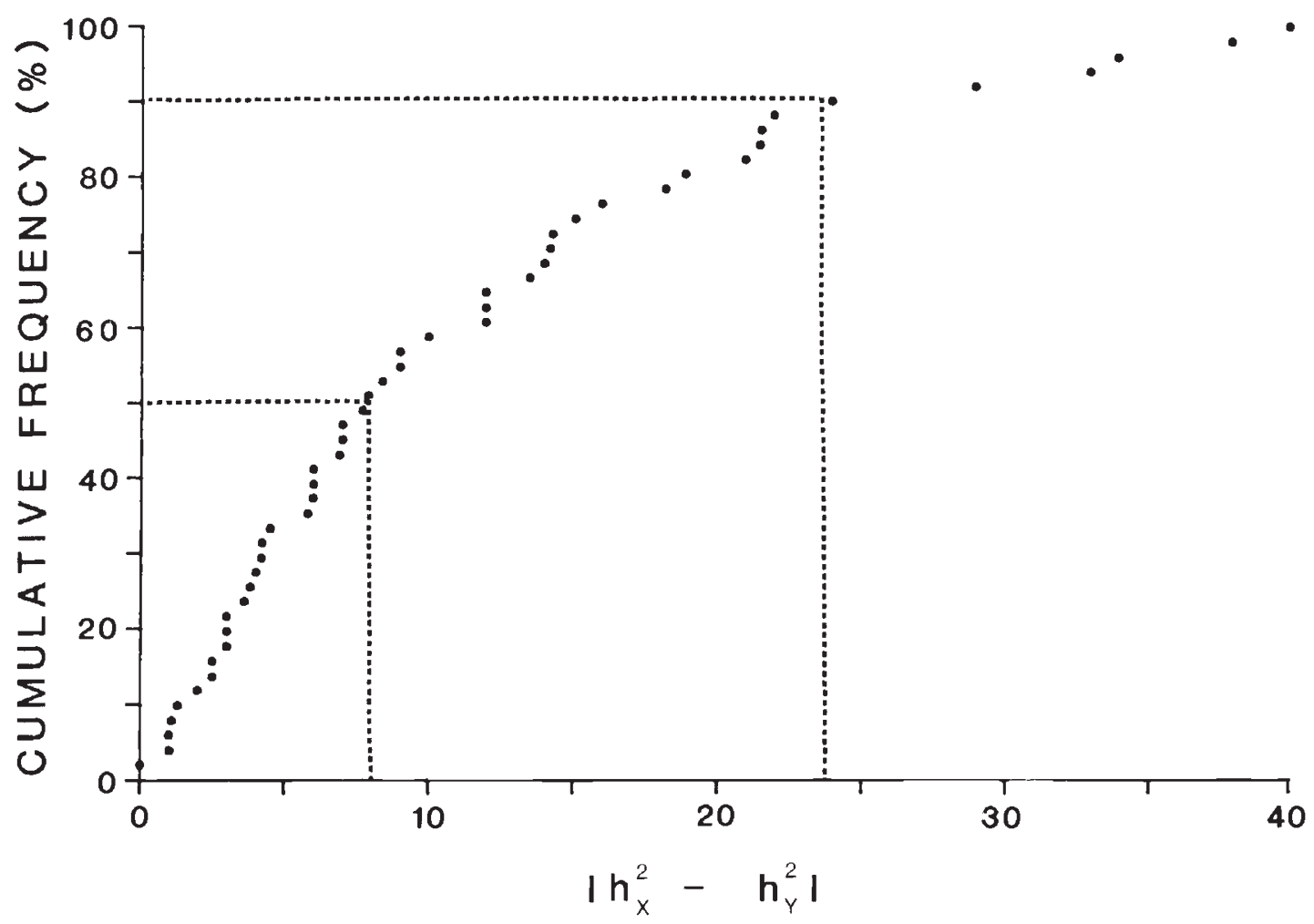

Figure 2 Cumulative frequency plot of the absolute difference between the 2 heritability estimates plotted in Fig. $1\left(h_{x}^{2}-h_{y}^{2}\right)$. 
$Y=2.47+0.33 X$, where $Y$ is realised $h^{2}$ and $X$ the other methods: the slope differs significantly from 1, $t=6 \cdot 02$ : data from table 2 of Frankham et al. 1968).

Although there may be statistically significant differences between methods it is clear from the scatter plot (fig. 1) that any bias is small relative to the total scatter. Provided comparisons are made on a relatively large number of estimates the effect of bias is unlikely to produce an erroneous conclusion. The size of the data base will depend in part upon the confidence region about each estimate. This will itself be a function of the estimated standard error and any potential bias in the central tendency of the heritability estimate not considered in the method of estimating the standard errors. Consider first the cumulative frequency of the absolute difference between the two estimates (fig. 2 ): such a plot tells us the probability with which the difference between two estimates will exceed a given value. Thus there is a 50 per cent probability that the absolute difference between $h^{2}$ estimated by offspring on parent regression and some other method $\left(\left|h_{x}^{2}-h_{y}^{2}\right|\right)$ will exceed 8 per cent. Although this difference is relatively small the cumulative frequency increases slowly and there is one chance in 10 that the difference will exceed 24 per cent. These large differences may reflect bias and/or high uncertainty in the estimates. Of the 51 estimates 29 have associated standard errors, though not in all cases for both estimates of $h^{2}$.
Consider those estimates in which both standard errors are given; in 14 out of 16 such cases each heritability estimate is within the confidence region of the other estimate. Of the 13 remaining cases in which only the standard error of one estimate is given, the estimate without an associated standard error is enclosed within the confidence region of the other estimate in 10 cases.

In summary, heritabilities estimated by different techniques may vary quite considerably, and there may be small biases in different techniques, but the estimated standard errors reasonably reflect the accuracy with which $h^{2}$ is estimated.

\section{THE DISTRIBUTION OF $h^{2}$}

We shall first consider only those estimates for which standard errors are given. Heritability estimates for life history traits span the full range from 0 to 100 per cent (fig. 3). However, the standard errors associated with $h^{2}$ are, in the case of two studies (Tait and Prabhu, 1970; Murphy et al., 1983), far too large to be considered reliable. These two studies have, therefore, been eliminated from the data set. The distribution of heritabilities for three groups (there are insufficient data for the physiological group) are presented in fig. 4: in all but a few cases the associated standard errors are relatively small. It is evident that few morphological traits have heritabilities less than 10 per cent

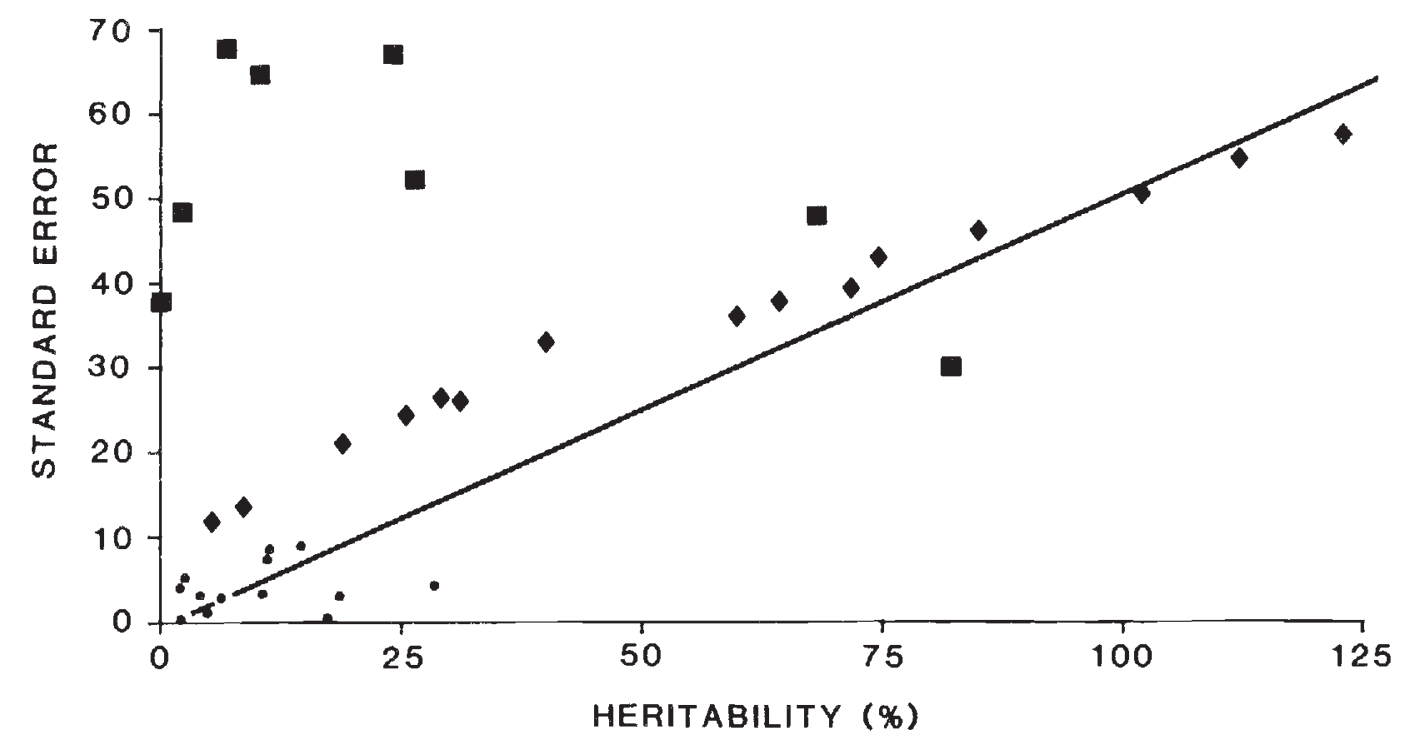

Figure 3 Scatter plots of heritability and associated standard errors for life history traits. Solid line indicates the relationship 2 S.E. $=h^{2}$; heritabilities above this line include zero within their confidence region. The closer the heritability is to the $x$ ( $h^{2}$ ) axis the more accurate the estimate. Data from Tait and Prabhu (1970); $\checkmark$ data from Murphy et al. (1983); see Appendix. 


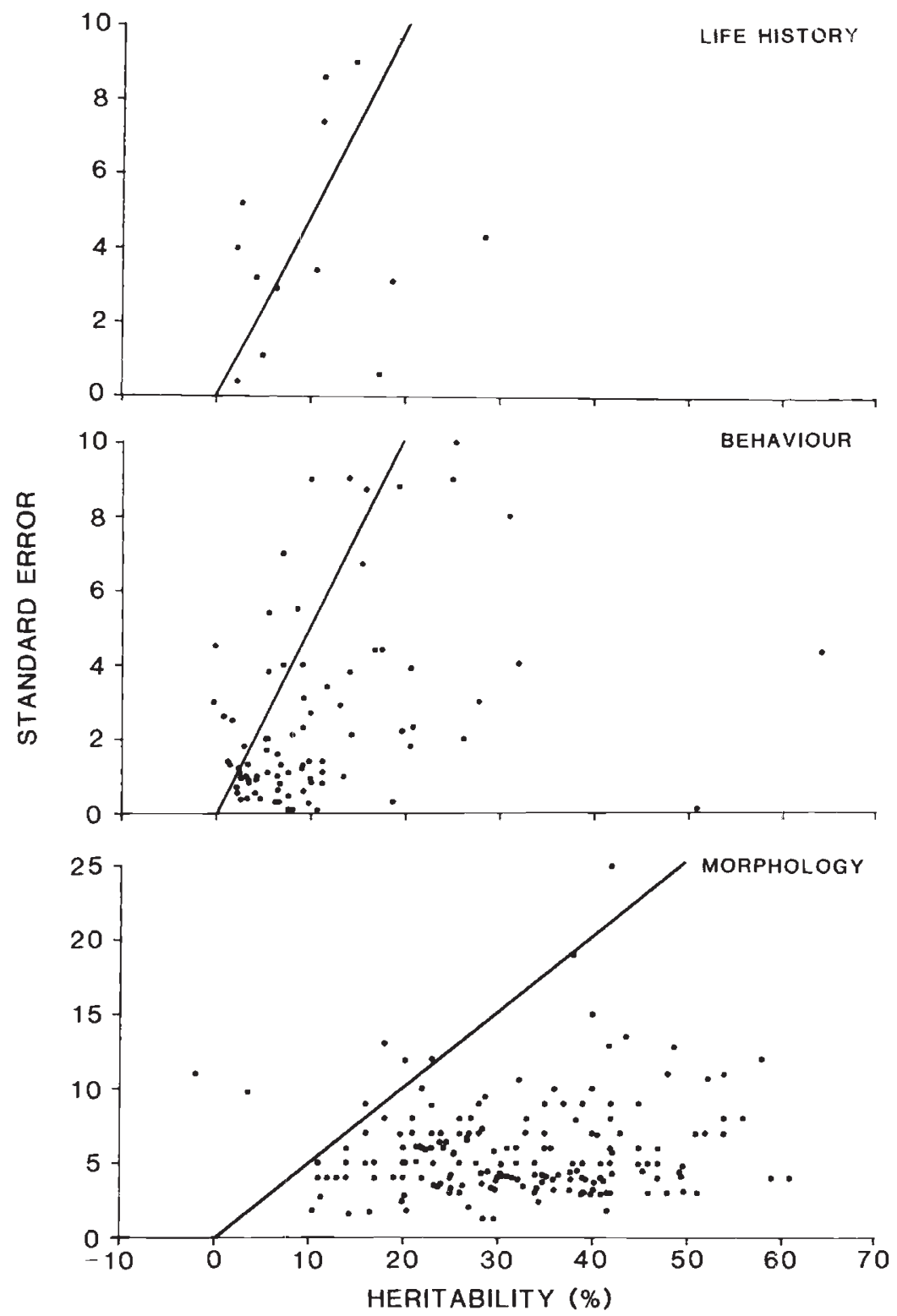

Figure 4 Scatter plots of heritability and associated standard errors. Solid line indicates 2 S.E. $=h^{2}$ : heritabilities above this line include zero within their confidence region. The closer the heritability is to the $x\left(h^{2}\right)$ axis the more accurate the estimate. For data sources seee Appendix.

whereas a significant proportion of behavioural and some life history traits fall within the $0-10$ per cent range. The range in $h^{2}$ of morphological traits is comparatively large spanning 10 per cent to 60 per cent, with little tendency for the standard error to increase with the estimate. On the other hand, the range in behavioural and life history heritabilities is much smaller, from 0 to 30 per cent. While the heritabilities of behavioural traits tend to be clustered within the region $0-10$ per cent those of life history traits are fairly evenly distributed, although the total number of data points is rather low. Therefore, while the data support the "classical" hypothesis that life history traits should have low heritabilities relative to traits less directly concerned with fitness, such as morphological traits, they also suggest that significant genetic variation is maintained and hence that 
other factors are intervening to present total erosion of variation. At the same time the low heritabilities of behavioural traits suggests that they may be under the same type of selection as life history traits.

The above analysis does not distinguish between traits within each grouping. Further, there are a large number of studies for which standard errors of $h^{2}$ are not given. To examine the distribu- tion of heritabilities both within and between traits we have included these studies and consider only the estimate itself (the two studies previously discarded have not been included). In any given study $h^{2}$ may have been estimated by several methods or in several different stocks. These separate estimates have been plotted on a number line to indicate the within-study variation in $h^{2}$; each trait has been stacked in an orderly fashion to illustrate the
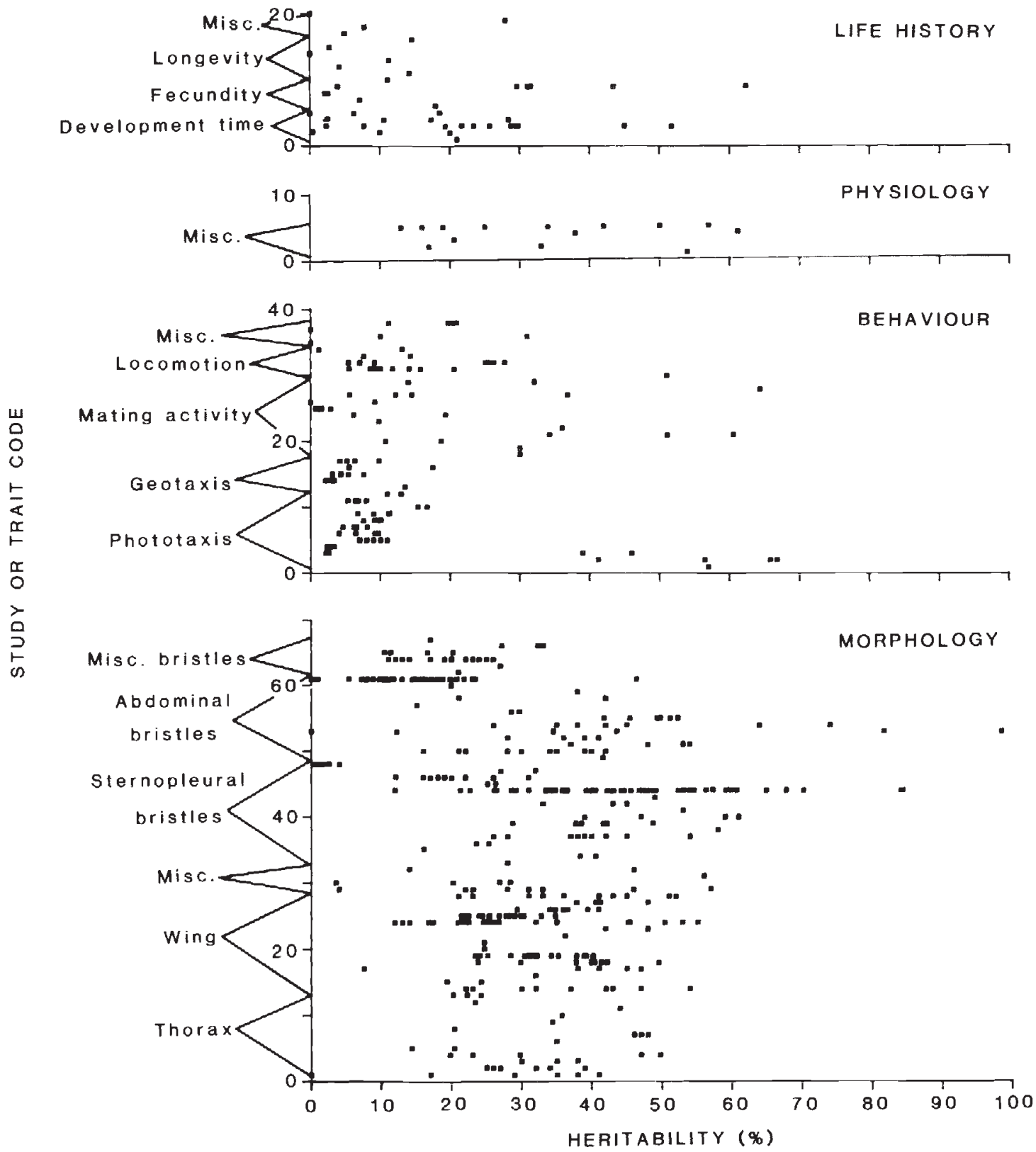

Figure 5 The distribution of heritability estimates within studies, among traits and among categories of traits. Fach line consists of all relevant heritability estimates for a given trait from a single study. For data sources see $A$ ppendix. 
distribution of $h^{2}$ within a study, within a trait, between traits and between groups (fig. 5, sources given in Appendix 1). Within the morphology grouping there is no indication that particular traits tend to differ from the rest. A priori we might predict morphologies directly related to size to be more closely related to fitness than, say, bristle number. However, Thoday (1958) argued that the number of steropleural chaeta must have adaptive significance since it differs between populations. Reeve (1960) suggested that bristle number per se is probably not significant but that the genes controlling bristle development also control some other trait that is under selection. Kearsey and Barnes (1970) demonstrated that chaeta number is under stabilising selection under laboratory conditions and that selection operates in the preadult stage before the bristles have developed, supporting the hypothesis of pleiotropy.

Except for three studies geotaxis and phototaxis appear to have low heritabilities whilst mating activity and locomotion tend to have a wider spread. Physiological heritabilities are scattered more or less evenly between 10 per cent and 70 per cent. The heritabilities of life history traits are more scattered than in fig. 4 , ranging from 0 to 60 per cent, though most values lie below 30 per cent. Heritability of development time is variable both within and between studies. Fecundity also tends to be variable. Given the potentially large standard errors associated with the heritabilities of life history traits (figs 3 and 4) the large values in fig. 5 must be viewed with caution. Nevertheless, the same general pattern emerges as previously described, viz., heritabilities of life history traits are generally lower than morphological traits but are not negligibly small and in some cases may be quite large. Behavioural traits appear to be similar to life history traits with respect to $h^{2}$ whereas physiological traits more closely match morphological traits.

To test the above conclusions further we constructed the cumulative frequency curves for each category using the median heritability from each study (fig. 6). There is a statistically significant difference between the distributions of morphology $h^{2}$ and life history $h^{2}$ (KolmogorovSmirnov $D=0.68, n$ (morph. $)=67, n$ (life hist.) $=$ $20, P<0.01)$ but not between the heritabilities of life history traits and behavioural traits $(D=0 \cdot 16$, $n$ (behav.) $=38, P>0.05$ ). The mean value of the morphology heritabilities is $31.9( \pm 1.45)$, of the

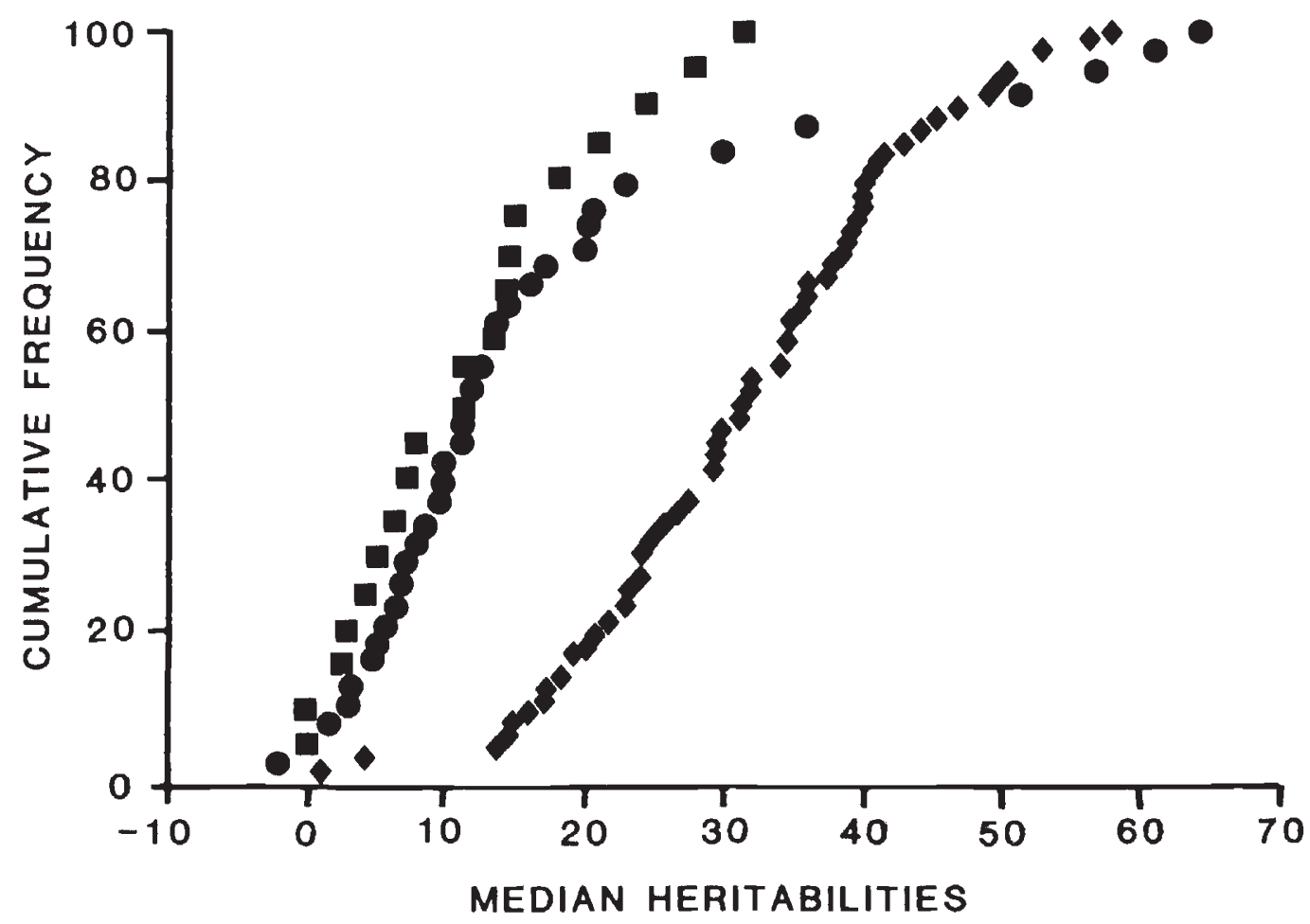

Figure 6 Cumulative frequency plots of the median heritabilities for morphological $(\bullet)$, behavioural $(\bullet)$ and life history $(\boldsymbol{\square})$ traits. For data sources see Appendix. 
life history $h^{2}, 11.94,( \pm 2.05)$ and of the behavioural $h^{2}, 17.99( \pm 2.84)$. The central tendencies of the distributions of the morphology $h^{2}$ and life history $h^{2}$ are significantly different $(t=$ 6.94, $P<0.01$; Mann-Whitney $U=124, P<0 \cdot 01$ ). Comparison between the central tendencies of the heritabilities of life history and behaviour is slightly complicated by significant differences between the variances $\left(F_{37,19}=3.67, P<0.05\right)$. Using a one-tailed test, based on the proposition that behavioural heritabilities will exceed life history heritabilities, a significant difference is obtained with the $t$-test for unequal variances ( $t=$ $1.73, \mathrm{df}=55.999, P<0.05)$ but not with the MannWhitney test $\left(U_{38,20}=326.5, z=-0.87, P>0.05\right)$. Obviously the above statistical analyses must be treated with caution: nevertheless, they do lend further support to the previously drawn conclusion that the heritabilities of life history traits are generally lower than those of morphological traits but approximately the same as behavioural traits.

Maynard Smith (1959) found that, with respect to longevity in $D$. subobscura, the correlations between parent and offspring of the same sex were considerably higher than correlations between parent and offspring of different sex (mean values of 0.241 and 0.078 respectively). Further, the correlations between sibs of the same sex was as large as the correlations between parent and offspring of the same sex suggesting "a negative association between longevity and other components of fitness" (Maynard Smith, 1959). In an extensive investigation of egg to adult viability in various populations of $D$. melanogaster Mukai and his colleagues (Mukai et al., 1974; Mukai and Yamaguchi, 1974; Mukai and Nakana, 1983; summarised in Charlesworth, 1987) found low levels of additive genetic variance. The amount of variation in northern stocks is consistent with maintenance by mutation alone but is far too large in southern stocks to be so maintained. Variable pleiotropy is one mechanism that coulci account for the excess additive genetic variance (Charlesworth, 1987).

THE PHENOTYPIC, GENETIC AND ENVIRONMENTAL CORRELATIONS

The phenotypic correlation is composed of the genetic and environmental correlations. While it would be most desirable to consider these latter two components separately there are generally very large standard errors associated with the environmental correlation and only a few papers present both correlations. Of the 30 available estimates of environmental and genetic correlations 15 come from a single study, that of Giesel et al. (1982). There is no significant correlation between the environmental and genetic correlation with or without this study $(r=-0 \cdot 11, t=-0 \cdot 4, n=15, P>$ 0.05 and $r=0.11, t=0.6, n=30, P>0.05)$. Similar results have been found for a wider range of organisms (Bell and Koufopanou, 1986).

The genetic correlation is significantly correlated with the phenotypic correlation (fig. 7, $r=$ $0.35, \quad n=53, \quad t=2.69, \quad P<0.05)$, though the relationship is weak. More significantly, both the phenotypic and genetic correlations are positive when the factors are morphology $\times$ morphology, or morphology $\times$ life history (no behavioural data are available) but may occur in any of the four quadrants for life history $\times$ life history traits. Seventeen of these genetic correlations are positive and 14 negative, supporting the variable pleiotropy hypothesis. However, this conclusion can be accepted only tentatively since the majority of the data come from two studies, which give somewhat different results. Rose and Charlesworth (1981) found a preponderance of negative correlations between life history traits in D. melanogaster ( 8 of 11) whereas Giesel et al. (1982) working with the same species, but different stock, obtained mainly positive correlations ( 10 of 15$)$ : this differencc is barely significant $(G=4 \cdot 06, \mathrm{df}=1, P<0 \cdot 05)$. In part, the difference might be due to differences in the traits measured, or they may reflect different evolutionary histories of the stocks. These data suggest that both the magnitude and sign of the correlation may be variable, as is also suggested by the change in sign in inbred stocks (Giesel et al., 1982). Thus data on the genetic and phenotypic correlations between traits in inbred lines, such as those of Mukai and Yamazaki (1971) demonstrating a negative correlation between development time and viability, may not be representative of wild stocks. Inbreeding may, indeed, be expected to produce positive covariation (Rose, 1984). Another factor that may affect the detection of negative genetic covariance is the effect of novel environments (Service and Rose, 1985).

The basic premise of the variable pleiotropy hypothesis is that high heritabilities may be maintained due to the antagonistic interaction between traits. If this is the case we would expect that at least one of each pair of such traits will have a high heritability and there will be a high genetic correlation between the traits, the sign of which will depend upon the particular traits. Estimates of the heritabilities, phenotypic and genetic 


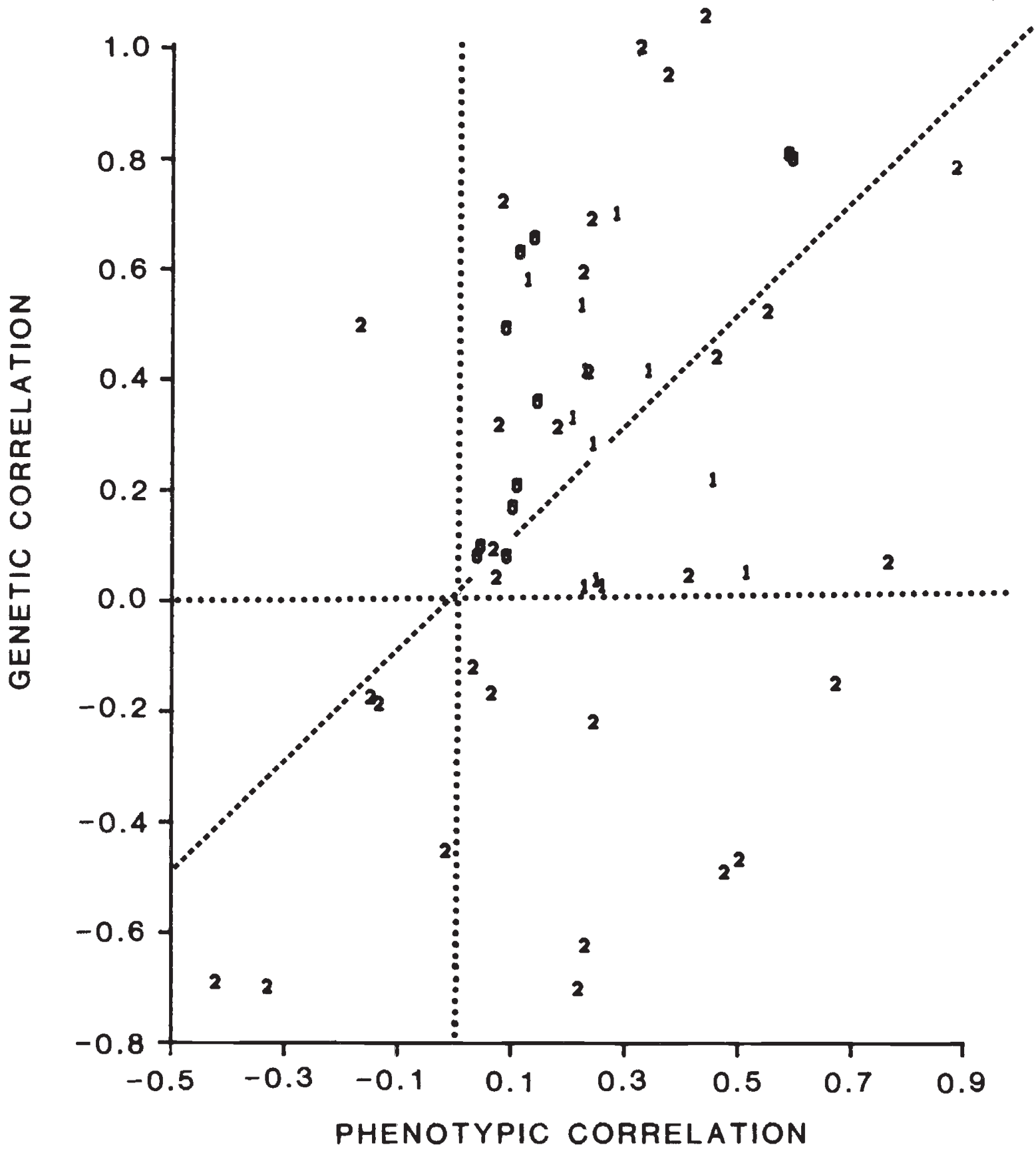

Figure 7 Scatter plot of genetic correlation on phenotypic correlation. 0; correlation between two morphological traits. 1; Correlation between a morphological and life history trait. 2; Correlation between two life history traits. Dotted lines indicate $x$ and $y$ axes and line of equality. All data from outbred stocks. Data from Clayton et al. (1957), Frahm and Kojima (1966), Giesel et al. (1982), Mackay (1981), Robertson (1953), Rose and Charlesworth (1981a), Sheridan et al. (1968), Tantawy and El-Helw (1966, 1970), Tantawy and Rakha (1964). 
Table 1 The heritabilities, phenotypic and genetic correlations of egg production and longevity in wild, outbred stocks of $D$. melanogaster and D. simulans.

\begin{tabular}{|c|c|c|c|c|c|c|c|}
\hline Egg production & $h^{2}$ & S.E. & \multicolumn{2}{|c|}{ Longevity } & $\begin{array}{l}\text { Phenotypic } \\
\text { correlation }\end{array}$ & $\begin{array}{l}\text { Genetic } \\
\text { correlation }\end{array}$ & Reference \\
\hline Lifetime & $7 \cdot 2$ & - & $14 \cdot 2$ & $\ldots$ & $0 \cdot 78$ & 0.07 & Tantawy and El-Helw (1966) \\
\hline Lifetime (simulans) & $11 \cdot 1$ & $7 \cdot 4$ & $14 \cdot 6$ & $9 \cdot 0$ & $0 \cdot 40$ & 0.03 & Tantawy and Rakha (1964) \\
\hline Days $1-5$ & $62 \cdot 3$ & - & $2 \cdot 8$ & $\cdots$ & $-0 \cdot 215$ & $-1 \cdot 43$ & Rose and Charlesworth (1981a) \\
\hline Days $6-10$ & $29 \cdot 6$ & - & $2 \cdot 8$ & -- & $0 \cdot 171$ & $0 \cdot 30$ & Rose and Charlesworth (1981a) \\
\hline Peak & $52 \cdot 9$ & $30 \cdot 1$ & $56 \cdot 0$ & $30 \cdot 2$ & 0.429 & $1 \cdot 04$ & Giesel et al. (1982) \\
\hline Day 2 & $91 \cdot 1$ & $29 \cdot 4$ & $56 \cdot 0$ & $30 \cdot 2$ & $0 \cdot 216$ & 0.578 & Giesel et al. (1982) \\
\hline
\end{tabular}

correlations of egg production and longevity are given in table 1. The estimates by Tantawy and his coworkers are "best" in the sense of being derived by a reliable method (offspring on parent regression) and having standard errors. The estimates of Rose and Charlesworth (1981a) are deficient in not having standard errors (though the data of Service and Rose (1985) suggest that the estimates are not unreliable) while those of Giesel et al. (1982) are derived only from full sib analysis and have large standard errors. The data of Tantawy and his coworkers indicate a low heritability for the two traits, a high phenotypic correlation and a low genetic correlation. In contrast, Rose and Charlesworth (1981a) found a high heritability for egg production but a low heritability for longevity. In all cases the genetic correlations are much larger in absolute magnitude than those of Tantawy et al. and in two cases are negative as expected by the variable pleiotropy hypothesis. Giesel et al. (1982) found high heritabilities for both egg production and longevity but the method of estimation and large standard errors make interpretation difficult. In no case is the genetic correlation negative. However, as the outbred lines were obtained by crossing a number of inbred lines (originating from the same geographic location) the results of Giesel et al. (1982) may be questionable (Rose, 1984).

These data suggest that, while the variable pleiotropy hypothesis is attractive, more studies, appropriately designed, are required to test its generality.

\section{CONCLUSIONS}

The large variability in the data set indicates that no general conclusions can be reached from single experiments, no matter how well designed or executed: it is easy to pick two heritability esti- mates from among the life history and morphology groups from which one could draw totally opposite conclusions. There is a need for better estimates of the amount of genetic variation in life history traits, these apparently being particularly prone to considerable error.

Despite biases and large confidence intervals about many estimates of heritability the data strongly suggest that life history traits do have consistently lower heritabilities than morphological traits but possibly not behavioural traits. However, there is considerable variation and life history traits may under some circumstances have large heritabilities. Negative genetic correlations between life history traits support the variable pleiotropy hypothesis but do not rule out the influence of other factors such as environmental variability (Mackay, 1980, 1981), or mutation rate (Hill, 1982) in maintaining high heritability of life history traits in Drosophila.

Acknowledgements We gratefully acknowledge the helpful comments of Drs R. Lewontin, Chris Chambers, Vasso Koufopanou, Martin Lechowitz, Graham Bell and Brian Charlesworth. This study was supported by N.S.E.R.C. operating grant A7764.

\section{REFERENCES}

AGuAdÉ, M., CUEllo, J. AND I'Revosti, A. 1981. Correlated responses to selection for wing length in allozyme systems of Drosophila melanogaster. Theor. Appl. Genet., 60, 317 327.

ANIJJELKOVIC, M. AND MAVINKOVIC, D. 1983. Selection for copulation ability of Drosophila subobscura in the absence of light. Behav. Genet., 13, 411-419.

BAPTIST, R. AND ROBERTSON, A. 1976. Asymmetrical responses to automatic selection for body size in Drosophila melanogaster. Theor. Appl. Genet., 47, 209-213.

BEARDMORE, I. A., LINTS, F. AND AL-BALDAWI, A. L. F. 1975 Parental age and heritability of sternopleural chaeta number in Drosophila melanogaster. Heredity, 34, 71-82.

BELL, G. ANI KOUFOPANOU, V. 1986. The cost of reproduction. Oxford Surveys in Evolutionary Ecology, Vol 3 (In press). 
BERVEN, K. A. AND GILL, D. E. 1983. Interpreting geographic variation in life-history traits. Amer. Zool., 23, 85-97.

BIRLEY, A. AND BURNES, B. 1973. Genetic variation of enzyme activity in a population of Drosophila melanogaster. Heredity, 31, 413-416.

BOWMAN, J. C. 1962. Recurrent selection. II. An experimental study with mice and Drosophila. Genet. Res., 3, 333-351.

BULMER, M. G, 1971. The effect of selection on genetic variability. Am. Nat., 105, 201-211.

CAVALLI-SFORZA, L. L. AND FELDMAN, M. W. 1976. Evolution of continuous variation, direct approach through joint distribution of genotypes and phenotypes. Proc. Natl. Acad. Sci., 73, 1689-1692.

CAVALli-SFORZA, L. L. AND FELDMAN, M. W. 1978. The evolution of continuous variation. III. Joint transmission of genotype, phenotype and environment. Genetics, 90, 391425.

CHARLESWORTH, B. 1987. The heritability of fitness. Dahlem Workshop on Sexual Selection (In press)

CHEVERUD, J. M. 1984. Quantitative genetics and developmental constraints on evolution by selection. J. Theor. Biol., $110,155-171$.

CHOO, J. 1975a. Genetic studies on the phototactic behavior in Drosophila melanogaster. I. Selection and genetic analysis. Jpn. J. Genet., 50, 205-215.

CHOO, J. $1975 b$. Genetic studies on the phototactic behavior in Drosophila melanogaster. II. Correlated response: lethal frequency and eclosion rhythm. Jpn. J. Genet., 50, 361-372.

CHOO, J. K. 1975c. Genetic studies on walking behavior in Drosophila melanogaster. I. Selection and hybridization analysis. Can. J. Genet. Cytol., 17, 535-542.

CLARKE, J. M., MAYNARD SMITH J. AND SONDHI, K. C. 1961. Asymmetrical response to selection for rate of development in Drosophila subobscura. Genet. Res., 2, 70-81.

CLAYTON, G. A., MORRIS, J. A. AND ROBERTSON, A. 1957. An experimental check on quantitative genetical theory. I. Short-term response to selection. J. Genet., 55, 131-151.

CONNOLLY, K. 1966. Locomotor activity in Drosophila. II. Selection for active and inactive strains. Anim. Behav., 14, 444-449.

CREUS, M. A. 1980. Interocellar bristles in Drosophila melanogaster. Metrical parameters in natural populations. Genet. Pol., 21, 173-179.

DEERY, B. J. AND PARSONS, P. A. 1972. Ether resistance in Drosophila melanogaster. Theor. Appl. Genet., 42, 208-214.

DEMPSTER, E. R. 1955. Maintenance of genetic heterogeneity. Cold Spr. Harb. Symp. Quant. Biol., XX, 25-32.

DICKERSON, G. E. 1955. Genetic slippage in response to selection for multiple objectives. Cold. Spr. Harb. Symp. Quant. Biol., $X X, 213-224$.

DINGLE, H. AND HEGMANN, J. P. (eds). 1982. Evolution and Genetics of Life Histories, Springer-Verlag, New York pp. 250.

DOBZHANSKY, T. AND SPASSKY, B. 1967. Effects of selection and migration on geotactic and phototactic behavior of Drosophila. I. Proc. Roy. Soc. Lond., B 168, 27-47.

DOBZHANSKY, T., SPASSKY, B., AND SVED, J. 1969. Effects of selection and migration on geotactic and phototactic behaviour of Drosophila. Proc. Roy. Soc. Lond., B 17.3, 191-207.

ECKSTRAND, I. A. 1981. Heritability of water-loss rate in Drosophila melanogaster. J. Hered., 72, 434-436.

EMLEN, J. M. 1980. A phenotypic model for the evolution of ecological characters. Theor. Pop. Biol., 17, 190-200.

FALCONER, D. S. 1977. Some results of the Edinburgh selection experiments with mice. Pollack, E., Kempthorne, O, and
Bailey, T. B. Jr. (eds). In Proceedings of the International Conference on Quantitative Genetics, Iowa State Univ. Press, Ames.

FALCONER, D. S. 1981. Introduction to Quantitative Genetics. 2nd ed., Longman, New York.

FISHER, R. A. 1930. The Genetical Theory of Natural Selection, Clarendon Press, Oxford.

FOGLEMAN, J.C. 1979. Oviposition site preference for substrate temperature in Drosophila melanogaster. Behav. Genet., 9, 407-412.

FRAHM, R. R. AND KOJIMA, K. 1966. Comparison of selection responses on body weight under divergent larval density conditions in Drosophila pseudoobscura. Genetics, 54, 625637

FRANKHAM, R., JONES, L. P., AND BARKER, J. S. F. 1968. The effects of population size and selection intensity for a quantitative character in Drosophila. I. Short-term response to selection. Genet. Res. Camb., 12, 237-248.

FULKER, D. W. 1966. Mating speed in Drosophila melanogaster: A psychogenetic analysis. Science, 153, 203-205.

GALlEGO. A. AND LOPEZ-FANJUL, C. 1983. The number of loci affecting a quantitative trait in Drosophila melanogaster revealed by artificial selection. Genet. Res., 42, 137-149.

GIESEL, J. T., MURPHY, P. A. AND MANLOVE, M. N. 1982. The influence of temperature on genetic interrelationships of life-history traits in a population of Drosophila melanogaster: what tangled data sets we weave. Am. Nat., $119,464-479$.

GRANT, B. AND METTLER, L. E. 1969. Disruptive and stabilizing selection on the "escape" behavior of Drosophila melanogaster. Genetics, 62, 625-637.

GRANT, P. R. AND PRICE, T. D. 1981. Population variation in continuously varying traits as an ecological genetics problem. Amer. Zool., 21, 795-811.

HADLER, N. M. 1964. Heritability and phototaxis in Drosophila melanogaster. Genetics, 50, 1269-1277.

HILL, W. G. 1982. Predictions of response to artificial selection from new mutations. Genet. Res. Camb., 40, 255-278.

HIRSCH, J. AND BOUDREAU, J. 1958. Studies in experimental behavior genetics I. The heritability of phototaxis in a population of Drosophila melanogaster. J. Comp. Physiol. Psychol., 51, 647-651.

IKEDA, H. AND MARUO, O. 1982. Directional selection for pulse repetition rate of the courtship sound and correlated responses occurring in several characters in Drosophila mercatorum. Jpn. J. Genet., 57, 241-258.

JOHNSTON, J. S. 1982. Genetic variation for anemotaxis (winddirected movement) in laboratory and wild-caught populations of Drosophila. Behav. Gent., 12, 281-293.

KEARSEY, M. J. AND BARNES, B. W. 1970. Variation for metrical characters in Drosophila populations. II. Natural selection. Heredity, 25, 11-21.

KEKIC, V. AND MARINKOVIC, D. 1974. Multiple-choice selection for light preference in Drosophila subobscura. Behav Genet., 4, 285-300.

KESSLER, S. 1969. The genetics of Drosophila mating behavior. II. The genetic architecture of mating speed in Drosophila pseudoobscura. Genetics, 62, 421-433.

LANDE, R. 1975. The maintenance of genetic variability by mutation in a polygenic character with linked loci. Genet Res., 26, 221-235.

LANDE, R. 1982. A quantitative genetic theory of life history evolution. Ecology, 63, 607-615.

LATTER, B. D. H. 1964. Selection for a threshold character in Drosophila. I. An analysis of the phenotypic variance on the underlying scale. Genet. Res., 5, 198-210. 
I.ATTER, B. D. H. AND ROBERTSON, \& 1962. The effects of inbreeding and artificial selection on reproductive fitness. Genet. Res., 3, 110-138.

LI:I, B. T. O. ANI PARSONS, P. A. 196\%. Selection, prediction and response. Bio. Rev., 43, 139-1/4.

LERNER, I. M. 1954. Genetic homeosta is, Wiley, New York.

LINTS, F. A., STOLL, J., GRUNWAY, G. IND IINTS, C. V. 1979. An attempt to select for increased ongevity in Drosophila melanogaster. Gerontology, 25, 192-204

LOPEZ-FANJUL, C. AND HILL, W. (3. 1973 a. Genetic differences between populations of Drosophila melanogaster for a quantitative trait. I. Lahoratory pi julations. Gener. Res., $22,51-68$.

LOPEZ-FANJUL, ( $\therefore$ AND H1L, w. (3. 19:3b. Genetic differences between populations of Drnsophila melanogaster for a quantitative trait. II. Wild and laboratory populations. Genet. Res., 22, 69-78.

MacBEAN, 1. T. AND PARSONS, P. A 196 . The genotypic control of the duration of copulation in i) osophila melanogaster. Experientia, XXII, 101-10?.

MACKAY. T. F. C 1980. Genetic variance, limess, and homeostasis in varying environments: an experimental check of the theory. Fitolution, $34,1219 \ldots 122.2$.

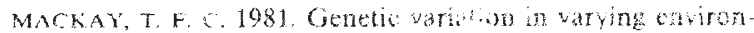
ments. Cicnet Ren, 27,79 9:

MANNING, A. 1961. The effects of artifial selection for mating speed in Drosophila melanogaster. Amm. Behav, 9, 82-42.

MARCOS, R, 1977. Estudio dol caracter quetas interocelares en Drosophila melanogaster. Calculo de su heredabilidad, Tesina de Licenciatura, Universidad de Barcelona.

MARKOW, T A 1979. A survey of intra- and interspecific variation for pupation height in Drosophila. Behav. Genet., 9, 209-217.

MARKOW, T, A. AND (L.AKK. A. (3. 1984. Correlated responke to phototactic selection. Behav. Genet., 14, 279-293.

MARKOW, T. A AND SMITH, W. 1. 1977. Genetic analysis of phototactic behavior in Drosophila simulans. Cienetics, 85 , 273-278.

MARKOW, T. A. AND SMITH, L. D. 1979. Genetics of phototactic behavior in Drosophila ananassae. a menber of the melanogaster spccies group. Behav. Genet., 9, 61-67.

MAYNARD SMITH, J. 1959. Sex-limited inheritance of longevity in Drosophila subobscura. J. Genetics, 56, 227-235.

MAYNARD SMITII, J. 1982. Fvolution and the Theory of Games, Cambridge Univ. Press, New York, 224 pp

MUKAI, T., CARDELLINO, R. A, WATANABE, T. K. AND CROW, J. F. 1974. The genetic variance for viability and its components in a local population of Drosophila melanogaster. Genetics, 78, 1195-1208.

MUKAI, T. AND NAGANO, S. 1983. The genetic structure of natural populations of Drosophila melanogaster. XVI Excess of additive genetic variance of viability. Genetics, $105,115-134$.

MUKAI. T. AND YAMAZAKI, T. 1971. The genetic structure of natural populations of Drosophila melanogaster. X. Developmental time and viability. Genetics, 69, 385-398.

MUKAI, T. AND YAMAGUC:HI, O. 1974. The genetic structure of natural populations of Drosophila melanogaster. Xl Genetic variability in a local population. Genetics, 76, 339-366.

MURPHY, P. A., GIESEl, J. T. AND MANLOVE, M. N. 1983. Temperature effects on life history variations in Drosophila simulans. Evolution, 37, 1181-1192.

MCDONAI.D, J. 1979. Genetic analysis of lines selected for wing vibration in Drosophila melanogaster. Behav. Cienet, 9, $579-584$.
UDONALI), P. 1967. On the evolution of dominance, overdominance and balanced polymorphism. Proc. Roy. Soc. B., $168,216-228$.

PARSONS, P. A. 1964. A diallel cross for mating speeds in Drosophila melanogaster. Genetics, 35, 141-151.

POlivanov, S. 1975. Response of Drosophila persimilis to phototactic and geotactic selection. Behav. Genet, , 5, 255267.

P()WEI, J. R. ANi I.ICHTENFELS. J. M. 1979. Population genetics of Drosophila amylase. 1. Genetic control of tissuespecific expression in D. pseudoobscura. Genetics, 92, 603612.

pRrVOSTI. A. 1967. Inversion heterozygosity and selection for wing length in Drosophila subobscura. Genet. Res., 10, $8 \mathrm{i}-93$.

IRICE, G. R. 1970. Selection and covariance. Nature, 227, 520521.

PROUT, T. 1962. The effects of stabilizing selection on the time of development in Drosophila melanogaster. Genet. Res. 3, 364-382.

PYlE, D. W. AND GROMKO, M. H. 1981. Genetic basis for repeated mating in Drosophila melanogaster. Am. Nat., 117, $133-146$.

PYYE, B W. AND RIOMMOND, R. \& 1979. Cienetic basis of arista! morphology in Drosophila melanogaser and its correlation with bevavor, selection for increused and decreased aristal branching. Behav. Genet., 9, 297-308.

RLEVE, E. C. R. 1960. Some genetic tests on asymmetry of sternopleural chaeta number in Drosophila. Genet. Res., I, $151-172$.

REEVE, F. C. AND ROBERTSON, F. W. 1953. Studies in quantita tive inheritance II. Analysis of a strain of Drosophila melanogaster selected for long wings. J. Genet., 51, 276-316.

REEVI, E. ( $\therefore$ R. ANI) ROBERTSON, F. W. 1954. Studies in quantitative inheritance VI. Sternite chacta number in Drosophila; a metameric quantitative character. $Z$. indukt. Abstamm.-u. Vererbhehre, 86, 269-288.

Fic H MOND R. \& 1969. Heritability of phototactic and geotactic responses in Drosophila pseudoobscura. Am. Nat., 103, 315-316.

RINGO, J. AND WOOD, D. 1983. Pupation site selection in Drosophila simulans. Behav. Genet., 13, 17-27.

RORгRTSON, A. 1955. Selection in animals: Synthesis. Cold Spr. Harb. Symp. Quant. Biol, XX, 225-229.

ROBERTSON, A. 1967. The spectrum of genetic variation 5-16. Lewontin, R. C. (ed.) In Population Biology and Evolution, Syracuse Univ. Press, New York.

ROBIRTSON, F. W. 1955. Selection response, and the properties of genetic variation. Cold Spr. Harb. Symp. Quant. Biol., $X X, 166-177$.

ROBEKISON, F. W. $1957 a$. Studies in quantitative inheritance X. Genetic variation of ovary size in Drosophila. J. Genet., $55,410-427$.

ROBERTSON, F. W. 1957 b. Studics in quantitative inheritance XI. Genetic and environmental correlation between body size and egg production in Drosophila melanogaster. J. Genet, $55,428-443$.

ROBERTSON, F. W. 1960. The ecological genetics of growth in Drosophila. 2. Selection for large body size on different diets. Genet. Res., 1, 305-318.

ROBERTSON, F. W. 1962. Changing the relative size of the body parts of Drosophila by selection. Genet. Res., 3, 169-180.

ROBFRTSON, F, W. 1963. The ecological geneties of growth in Drosophila. 6 . The genetic correlation between the duration of the larval period and body size in relation to larval diet. Genet. Res., 4, 74-92. 
ROBERTSON, F. W. 1964. The ecological genetics of growth in Drosophila. 7. The role of canalization in the stability of growth relations. Genet. Res., 5, 107-126.

ROBERTSON, F. W. AND REEVE, E. 1952. Studies in quantitative inheritance. 1. The effects of selection of wing and thorax length in Drosophila melanogaster. I. Genet., 50, 414-448.

ROSE, M. R. 1982. Antagonistic pleiotropy, dominance and genetic variation. Heredity, 48, 63-78.

ROSE, M. R. 1983. Theories of life-history evolution. Amer. Zool., 23, 15-23.

ROSE, M. R. 1984. Genetic covariation in Drosophila life history: untangling the data. Am. Nat., 123, 565-569.

ROSE, M. R. AND CHARLESWORTH, B. 1981a. Genetics of life history in Drosophila melanogaster. I. Sib analysis of adult females. Genetics, 97, 173-186.

ROSE, M. R. AND CHARLESWORTH, B. $1981 b$. Genetics of life history in Drosophila melanogaster. II. Exploratory selection experiments. Genetics, 97, 1187-1196.

SANG, J. H. 1962. Selection for rate of larval development using Drosophila melanogaster cultured axenically on deficient diets. Genet. Res., 3, 90-99.

SANG, J. H. AND CLAYTON, G. A. 1957. Selection for larval development time in Drosophila. J. Hered., 48, 265-270.

SEN, B. K. AND ROBERTSON, A. 1964. An experimental examination of methods for the simultaneous selection of two characters using Drosophila melanogaster. Genetics, 50 , 199-209.

SERV1CE, P. M. AND ROSE, M. R. 1985. Genetic covariation among life-history components: the effect of novel environments. Evolution, 39, 943-945.

SEWELL, D., BURNET, B. AND CONNOLLY, K. 1975. Genetic analysis of larval feeding behaviour in Drosophila melanogaster. Genet. Res., 24, 163-173.

SHERIDAN, A. K., FRANKHAM, R., JONES, L. P., RATHIE, K. A. AND BARKER, J. S. F. 1968. Partitioning of variance and estimation of genetic parameters for various bristle number characters of Drosophila melanogaster. Theor: Appl. Genet., $38,179-187$.

SLATKIN, M. 1970. Selection and polygenic characters. Proc. Natl. Acad. Sci., 66, 87-93.

SONDHI, K. C. 1960 . Selection for a character with a bounded distribution of phenotypes in Drosophila subobscura. $J$. Genet., 193-221.

SORENSEN, D. A. AND HILL., W. G. 1982. Effect of short term directional selection on genetic variability: experiments with Drosophila melanogster. Heredity, 48, 27-33.

SORENSON, D. A. AND HILL, W. G. 1983. Effects of disruptive selection on genetic variance. Theor. Appl. Genet., 65, 173180.

SPIESS, E. B. AND YU, H. 1975. Relative mating activity of the sexes in homokaryotypes of Drosophila persimilis from a redwoods population. Behav. Genet., 5, 203-216.

SPUHLER, K. P., CRUMPACKER, I). W., WILLIAMS, J. S. AND BRADLEY, B. P. 1978. Response to selection for mating speed and changes in gene arrangement frequencies in descendents from a single population of Drosophila pseudoobscura. Genetics, 89, 729--749.

STEINER, W. W. M. 1974. Enzyme polymorphism and dessication resistance in two species of Hawaiian Drosophila. Ph.D. Dissertation. Univ. of Hawaii (Mic. no. 75-5041). University Microfilms, Ann Arbor, MI.
TAIT, W. M. AND PRABHU, S. S. 1970. Fecundity and hatchability in Drosophila melitnogaster. J. Genet., 60, 152-158.

TANTAWY, A. O. 195 a. Selection for long and short wing lengths in Drosophila melanogaster with different systems of mating. Genetica, 28, 231-262.

TANTAWY, A. O. 19560 . Response to selection and changes of genetic variability for wing length in Drosophila melanogaster with brother-sister matings. Genetica, 28, $177-200$.

TANTAWY, A. O. 1961. Effects of temperature on productivity and genetic variance of body size in populations of Drosophila pseudoobscura. Genetics, 46, 227-238.

TANTAWY, A. O. 196.4. Studies on natural populations of Drosophila. III. Morphological and genetic differences of wing length in Drosophila melanogaster and D. simulans in relation to season. Evolution, 18, 560-570.

TANTAWY, A. O. AND TAYEL, A. A. 1970. Studies on natural populations of Drosophila. X. Effects of disruptive and stabilizing selection on wing length and the correlated response in Drosophila melanogaster. Genetics, 65, 121-132.

TANTAWY, A. O. AND RAKHA, F. A. 1964. Studies on natural populations of Drosophila. IV. Genetic variances of and correlations between four characters in $D$. melanogaster and D. simulans. Genetics, 50, 1349-1355.

T'ANTAWY, A. O., MA! LAH, G. S. AND TEWFIK, H. R. 1964. Studies on natura! populations of Drosophila. II. Heritability and response to selection for wing length in Drosophila melanogaster and $D$. simulans at different temperatures. Genetics, 49, 935-748.

TANTAWY, A. O. AND EL-HELW, M. R. 1966. Studies on natural populations of Drosophila. V. Correlated response to selec. tion in Drosophila melanogaster. Genetics, 53, 97-110.

TANTAWY, A. O. AND EL-HELW, M. R. 1970. Studies on natural populations of Losophila. XI. Some fitness components and their heritabilities in natural and mutant populations of Drosophila melanogaster. Genetics, 64, 79-91.

THODAY, J. M. 1958. Homeostasis in a selection experiment. Heredity, 12, 401-415.

TORO, M. A. AND CHARLESWORTH, B. 1982. An attempt to detect genetic idriation in sex ratio in Drosophila melanogaster. He:edity, 49, 199-209.

TURELLI, M. 1984. Huritable genetic variation via mutationselection halance; Lerch's zeta meets the abdominal bristle. Theor. Pop. Biol., 25, 138-193.

VAN DIJKEN, F. R. AND SCHARLOO, W. 1979. Divergent selection on locomoto activity in Drosophila melanogaster. 1. Selection respons. Behav. Genet., 9, 543-553.

VAN VALEN, L. 1965. Morphological variation and width of the ecological niche. Am. Nat., 99, 377-390.

YOO, B. H. 1980. Long-ierm selection for a quantitative character in large replicate populations of Drosophila melanogaster. I, Response to selection. Genet. Res., 35, 1-17.

YOUSIF, M. E. AND SKIBINSKI, D. O. F. 1982, Directionaldisruptive selection in Drosophila melanogaster. Heredity, 49, $71-79$.

WATANABE, T. K. AN! ANDERSON, W. W. 1976. Selection for geotaxis in Drosophila melanogaster: heritability, degree of dominance, and correlated responses to selection. Behav. Genet., 6, 71-86.

WOOD, D. AND RINGO, J. M. 1982. Artificial selection for altered male wing display in Drosophila simulans. Behav. Genet., $12,449-458$. 
Appendix 1 A listing of the data plotted in figs 3, 4, 5 and 6

\begin{tabular}{|c|c|c|c|c|c|c|}
\hline $\begin{array}{l}\text { Trait/ } \\
\text { study } \\
\text { code }\end{array}$ & Species* & Trait & $\begin{array}{l}\text { Estimation } \\
\text { method }+\end{array}$ & S.E. $\div$ & Tahle $\$$ & Reference \\
\hline \multicolumn{7}{|c|}{ Morphology } \\
\hline 1 & $\mathrm{~m}$ & thorax length & 0,4 & $\mathrm{Y}$ & 10 & Reeve and Robertson (1953) \\
\hline 2 & $\mathrm{~m}$ & thorax length & 1 & $\mathrm{Y}$ & 2 & Robertson (1955) \\
\hline 3 & $\mathrm{~m}$ & thorax length & 1 & $\mathrm{~N}$ & 2 & Robertson (1960) \\
\hline 4 & $\mathrm{~m}$ & thorax length & 1,4 & $\mathrm{Y}$ & 5,8 & Robertson (1957) \\
\hline 5 & $\mathrm{~m}$ & thorax length & 1 & $\mathrm{Y}$ & p. 210 & Baptist and Robertson (1976) \\
\hline 6 & $\mathrm{~m}$ & thorax length & 0 & $\mathrm{Y}$ & 1 & Tantawy (1956a) \\
\hline 7 & $\mathrm{~m}$ & thorax length & 0 & $\mathrm{Y}$ & 2 & Tantawy $(1956 b)$ \\
\hline 8 & $\mathrm{~m}$ & thorax length & 0 & $\mathrm{Y}$ & 4 & Tantawy and Rakha (1964) \\
\hline 9 & $\mathrm{~m}$ & thorax length & 0 & Y & 1 & Tantawy and Tayel (1970) \\
\hline 10 & $\mathrm{~m}$ & thorax length & 0 & $\mathrm{Y}$ & 7 & Tantawy and El-Helw (1970) \\
\hline 11 & $\mathrm{~m}$ & thorax length & 0 & $\mathrm{~N}$ & p. 544 & van Dijken and Scharloo (1979) \\
\hline 12 & s & thorax length & 0 & $\mathrm{Y}$ & 4 & Tantawy and Rakha (1964) \\
\hline 13 & $\mathrm{p}$ & thorax length & 0 & $\mathrm{~N}$ & 5 & Tantaway (1961) \\
\hline 14 & $\mathrm{~m}$ & wing length & 0,4 & $\mathrm{Y}$ & 10 & Reeve and Robertson (1953) \\
\hline 15 & $\mathrm{~m}$ & wing length & 1 & $\mathrm{~N}$ & 3 & Robertson and Reeve (1952) \\
\hline 16 & $\mathrm{ml}$ & wing length & 0 & $\mathrm{Y}$ & 1 & Tantaway $(1956 a)$ \\
\hline 17 & $\mathrm{~m}$ & wing length & 0,1 & $\mathrm{Y}$ & 2 & Tantawy $(1956 b)$ \\
\hline 18 & $\mathrm{~m}$ & wing length & 3 & $\mathrm{Y}$ & 3 & Tantawy (1964) \\
\hline 19 & $m$ & wing length & 0 & $\mathrm{Y}$ & 2 & Tantawy et al. (1964) \\
\hline 20 & $\mathrm{~m}$ & wing length & 0 & $\mathrm{~N}$ & 1 & Tantawy and El-Helw (1966) \\
\hline 21 & $\mathrm{~m}$ & wing length & 0 & $\mathrm{Y}$ & 3 & Tantawy and Rakha (1964) \\
\hline 22 & $\mathrm{~m}$ & wing length & 0 & $\mathrm{~N}$ & 1 & Tantawy and Tayel $(1970)$ \\
\hline 23 & $\mathrm{~m}$ & wing length & 1 & $N$ & p. 130 & Latter and Robertson (1962) \\
\hline 24 & $\mathrm{~m}, \mathrm{~s}$ & wing length & 1 & $\mathrm{~N}$ & 2 & Aguadé et al. (1981) \\
\hline 25 & s & wing length & 0 & $\mathrm{Y}$ & 4 & Tantawy and Rakha (1964) \\
\hline 25 & $s$ & wing length & 0 & $\mathrm{Y}$ & 2 & Tantawy et al. (1964) \\
\hline 26 & $\mathrm{~s}$ & wing length & 3 & $\mathrm{Y}$ & 3 & Tantawy (1964) \\
\hline 27 & $\mathrm{p}$ & wing length & 0 & $\mathrm{~N}$ & 5 & Tantawy (1961) \\
\hline 28 & sub & wing length & 1 & $\mathrm{Y}$ & 1 & Prevosti (1967) \\
\hline 29 & $\mathrm{p}$ & body weight & 1,3 & $\mathrm{~N}$ & 1 & Frahm and Kojima (1966) \\
\hline 30 & $\mathrm{~m}$ & body weight & 0 & $\mathrm{Y}$ & 8 & Mackay (1981) \\
\hline 31 & $\mathrm{~m}$ & wing : thorax ratio & 1 & $\mathrm{Y}$ & p. 172 & Robertson (1962) \\
\hline 32 & $\mathrm{~m}$ & ovariole Nos. & 1 & $\mathrm{Y}$ & 3 & Robertson (1957a) \\
\hline 33 & sub & occelli Nos. & 1 & $N$ & p. 200 & Sondhi $(1960)$ \\
\hline 34 & $m$ & sternopleural bristles 2 sides & 1,2 & $\mathrm{Y}$ & p. 208 & Latter (1964) \\
\hline 35 & $\mathrm{~m}$ & sternopleural bristles 2 sides & 0 & $\mathrm{Y}$ & 3 & Lopez-Fanjul and Hill (1973b) \\
\hline 36 & $\mathrm{~m}$ & sternopleural bristles 2 sides & 1,2 & $N$ & 1 & Reeve $(1960)$ \\
\hline 37 & $\mathrm{~m}$ & sternopleural bristles 2 sides & 0,1 & Y & 1 & Lopez-Fanjul and Hill (1973a) \\
\hline 38 & $\mathrm{~m}$ & sternopleural bristles 2 sides & 0 & $\mathrm{Y}$ & 3 & Lopez-Fanjul and Hill (1973b) \\
\hline 39 & $\mathrm{~m}$ & sternopleural bristles 2 sides & 0 & $\mathrm{Y}$ & 1,2 & Mackay (1981) \\
\hline 40 & In & sternopleural bristles 2 sides & 0,1 & $\mathrm{Y}$ & 1 & Gallego and Lopez-Fanjul (1983) \\
\hline 41 & $\mathrm{~m}$ & sternopleural bristles 2 sides & $?$ & $\mathrm{~N}$ & p. 544 & van Dijken and Scharloo (1979) \\
\hline 42 & $\mathrm{~m}$ & sternopleural bristles 2 sides & 1 & $N$ & 1 & Yousif and Skibinski (1982) \\
\hline 43 & $\mathrm{~m}, \mathrm{i}$ & sternopleural bristles 2 sides & 1 & $N$ & p. 201 & Lints et al. (1979) \\
\hline 44 & in & sternopleural bristles 2 sides & 0,3 & $\mathrm{~N}$ & $1,3,4$ & Beardmore et al. (1975) \\
\hline 45 & $\mathrm{~m}$ & sternopleural bristles 1 side & 1 & $\mathrm{Y}$ & p. 208 & Latter (1964) \\
\hline 46 & $\mathrm{~m}$ & sternopleural bristles 1 side & 0,2 & $\mathrm{Y}$ & 10 & Sheridan et al (1968) \\
\hline 47 & in & sternopleural bristles 1 side & 1,4 & $\mathrm{Y}$ & p. 202,5 & Sen and Robertson (I964) \\
\hline 48 & $\mathrm{~m}$ & sternopleural bristles $|\mathrm{L}-\mathrm{R}|$ & 2 & $N$ & 2 & Reeve (1960) \\
\hline 49 & $\mathrm{~m}$ & abdominal bristles 2 sternites & 1,2 & $\mathrm{Y}$ & p. 207 & Latter (1964) \\
\hline 50 & $\mathrm{~m}$ & abdominal bristles 2 sternites & 0,2 & $\mathrm{Y}$ & 5 & Sheridan et al. (1968) \\
\hline 51 & m & abdominal bristles 2 sternites & $0,1,3,4$ & $\dot{Y}$ & p. 135 & Clayton et al. (1957) \\
\hline 52 & $\mathrm{~m}$ & abdominal bristles 2 stcrnites & 1 & $\mathrm{~N}$ & p. 120 & Latter and Robertson (1962) \\
\hline 53 & $\mathrm{~m}$ & abdominal hristles 2 sternites & 1 & $\mathrm{Y}$ & 12 & Bowman (1962) \\
\hline 54 & $\mathrm{~m}$ & abdominal bristles 2 sternites & 0,1 & Y & 6,1 & Sorenson and Hill $(1982,1983)$ \\
\hline 55 & $\mathrm{~m}$ & abdominal bristles 2 sternites & 0,2 & $\mathrm{Y}$ & 4,5 & Mackay (1981) \\
\hline 56 & $\mathrm{~m}$ & abdominal bristles 1 sternite & 2 & $\mathrm{Y}$ & p. 207 & Latter (1964) \\
\hline 57 & $\mathrm{~m}$ & abdominal bristles 1 sternite & 2 & $\mathrm{Y}$ & $3,4,5$ & Sheridan et al. (1968) \\
\hline 58 & $\mathrm{~m}$ & abdominal bristles 1 sternite & 1,4 & $\mathrm{Y}$ & p. 202,5 & Sen and Robertson (1964) \\
\hline
\end{tabular}


Appendix 1 continued

\begin{tabular}{lll}
$\begin{array}{l}\text { Trait/ } \\
\text { study } \\
\text { code }\end{array}$ & Species* & Trait \\
\hline 59 & $\mathrm{~m}$ & abdominal bristles 1 sternite \\
60 & $\mathrm{~m}$ & abdominal bristles 1 sternite \\
61 & $\mathrm{~m}$ & abdominal bristles 1 sternite \\
62 & $\mathrm{~m}$ & abdominal bristles total Nos. \\
63 & $\mathrm{~m}$ & scuttellar bristles \\
64 & $\mathrm{~m}$ & 2nd coxal \\
65 & $\mathrm{~m}, \mathrm{~s}$ & aristal bristles \\
66 & $\mathrm{~m}$ & interocellar bristles \\
67 & $\mathrm{~m}$ & interocellar bristles
\end{tabular}

Estimation

method $\dagger$ S.E. $\neq$ Table§ Reference

Behaviour

$\begin{array}{llll}2 & \text { N } & - & \text { Reeve and Robertson (1954) } \\ 2 & \text { Y } & 1 & \text { Yoo (1980) } \\ 1 & \text { N } & 3 & \text { Frankham et al. }(1968 a) \\ 2 & \text { Y } & \text { p. } 186 & \text { Sheridan et al. (1968) } \\ 2 & \text { N } & 3 & \text { Latter (1964) } \\ 0,2 & \text { Y } & 11,12,13 & \text { Sheridan et al. }(1968) \\ 1 & \text { Y } & \text { p. } 299 & \text { Pyle and Richmond (1979) } \\ 0 & \text { Y } & 6 & \text { Creus (1980) } \\ ? & \text { N } & - & \text { Marcos (1977) (cited by Creus, 1980) }\end{array}$

\begin{tabular}{rll}
1 & $\mathrm{~m}$ & phototaxis \\
2 & $\mathrm{~m}, \mathrm{~s}$ & phototaxis \\
3 & $\mathrm{~m}$ & phototaxis \\
4 & $\mathrm{~m}$ & phototaxis \\
5 & $\mathrm{~m}, \mathrm{~s}$ & phototaxis \\
6 & $\mathrm{~s}, \mathrm{~s}$ & phototaxis \\
7 & $\mathrm{a}$ & phototaxis \\
8 & $\mathrm{p}$ & phototaxis \\
9 & $\mathrm{p}$ & phototaxis \\
10 & $\mathrm{p}$ & phototaxis \\
11 & $\mathrm{pers}, \mathrm{s}$ & phototaxis \\
12 & $\mathrm{sub}$ & phototaxis \\
13 & $\mathrm{~m}$ & geotaxis \\
14 & $\mathrm{p}$ & geotaxis \\
15 & $\mathrm{p}$ & geotaxis \\
16 & $\mathrm{p}$ & geotaxis \\
17 & $\mathrm{pers}, \mathrm{s}$ & geotaxis \\
18 & $\mathrm{~m}$ & mating speed \\
19 & $\mathrm{~m}, \mathrm{~s}$ & repeat mating \\
20 & $\mathrm{~m}, \mathrm{i}$ & wing vibration \\
21 & $\mathrm{~m}, \mathrm{~s}$ & mating speed \\
22 & $\mathrm{~m}, \mathrm{~s}$ & mating speed \\
23 & $\mathrm{~m}, \mathrm{~s}$ & copulation duration \\
24 & $\mathrm{p}, \mathrm{s}$ & mating speed \\
25 & $\mathrm{p}, \mathrm{s}$ & mating speed \\
26 & $\mathrm{~s}, \mathrm{~s}$ & wing display \\
27 & $\mathrm{pers}, \mathrm{i}$, & mating speed \\
28 & $\mathrm{sub}$ & copulation ability \\
29 & $\mathrm{merc}, \mathrm{s}$ & pulse interval \\
30 & $\mathrm{~m}$ & locomotion \\
31 & $\mathrm{~m}$ & locomotion \\
32 & $\mathrm{~m}$ & walking speed \\
33 & $\mathrm{~m}, \mathrm{~s}$ & walking speed \\
34 & $\mathrm{~m}, \mathrm{~s}$ & anemotaxis \\
35 & $\mathrm{~s}, \mathrm{~s}$ & pupation height \\
36 & $\mathrm{~m}, \mathrm{~s}$ & pupation height \\
37 & $\mathrm{~m}, \mathrm{~s}$ & oviposition preference \\
38 & $\mathrm{~m}, \mathrm{~s}$ & larval feeding rate \\
& & \\
\hline
\end{tabular}

$\begin{array}{llll}2 & \text { N } & \text { p. } 650 & \text { Hirsch and Boudreau (1958) } \\ 2 & \text { N } & \text { p. } 1274 & \text { Hadler (1964) } \\ 1 & \text { Y } & 2 & \text { Choo (1975a) } \\ 1 & \text { Y } & \text { p. } 363 & \text { Choo (1975b) } \\ 1 & \text { N } & \text { p. } 284 & \text { Markow and Clark (1984) } \\ 1 & \text { Y } & 1 & \text { Markow and Smith (1977) } \\ 1 & \text { Y } & 1 & \text { Markow and Smith (1979) } \\ 1 & \text { Y } & \text { p. } 32 & \text { Dobzhansky and Spassky (1967) } \\ 1 & \text { Y } & 5 & \text { Dobzhansky et al. (1969) } \\ 0 & \text { Y } & 1 & \text { Richmond (1969) } \\ 1 & \text { Y } & 2 & \text { Polivanov (1975) } \\ 1 & \text { N } & 2 & \text { Kekic and Marinkovic (1974) } \\ 1 & \text { Y } & \text { p. } 78 & \text { Watanabe and Anderson (1976) } \\ 1 & \text { Y } & \text { p. } 32 & \text { Dobzhansky and Spassky (1967) } \\ 1 & \text { Y } & 5 & \text { Dobzhansky et al. (1969) } \\ 0 & \text { Y } & 1 & \text { Richmond (1969) } \\ 1 & \text { Y } & 2 & \text { Polivanov (1975) } \\ 1 & \text { N } & \text { p. } 84 & \text { Manning (1961) } \\ 1 & \text { N } & \text { p. } 136 & \text { Pyle and Gromko (1981) } \\ 1 & \text { Y } & \text { p. } 582 & \text { McDonald (1979) } \\ 2 & \text { N } & 6 & \text { Parsons (1964) } \\ 2 & \text { N } & \text { p. } 205 & \text { Fulker (1966) } \\ 2 & \text { N } & \text { p. } 102 & \text { MacBean and Parsons (1966) } \\ 1 & \text { Y } & \text { p. } 424 & \text { Kessler (1969) } \\ 1 & \text { Y } & 1 & \text { Spuhler et al. (1978) } \\ 1 & \text { Y } & \text { p. } 451 & \text { Wood and Ringo (1982) } \\ 1 & \text { N } & 4 & \text { Spiess and Yu (1975) } \\ 0 & \text { Y } & 2 & \text { Andjelkovic and Marinkovic (1983) } \\ 1 & \text { Y } & \text { p. } 247 & \text { Ikedo and Maruo (1982) } \\ 0 & \text { Y } & \text { p. } 455 & \text { Connolly (1966) } \\ 0,1 & \text { Y } & 2 & \text { van Dijken and Scharloo (1979) } \\ 1 & \text { Y } & 2 & \text { Choo (1975c) } \\ 1 & \text { Y } & \text { p. } 635 & \text { Grant and Mettler (1969) } \\ 1 & \text { Y } & \text { p. } 285 & \text { Johnston (1982) } \\ 1 & \text { Y } & \text { p. } 20 & \text { Ringo and Wood (1983) } \\ 1 & \text { Y } & \text { p. } 214 & \text { Markow (1979) } \\ 1 & \text { Y } & 2 & \text { Fogleman (1979) } \\ 1 & & 1 & \text { Sewell et al. (1975) } \\ & & & \\ 1 & \text { Y } & & \\ 1 & & & \end{array}$

Physiology

$\begin{array}{lll}1 & \text { mim } & \text { water loss } \\ 2 & \mathrm{~m} & \text { water loss } \\ 3 & \mathrm{~m} & \text { enzyme activity } \\ 4 & \mathrm{~m} & \text { ether resistance } \\ 5 & \mathrm{p} & \text { enzyme activity }\end{array}$

$\begin{array}{ll}\mathrm{Y} & 4.1 .1 \\ \mathrm{~N} & \text { p. } 434 \\ \mathrm{~N} & \text { p. } 416 \\ \mathrm{~N} & \text { p. } 212 \\ \mathrm{Y} & 3\end{array}$

Steiner (1974)

Eckstrand (1981)

Birley and Barnes (1973)

Deery and Parsons (1972)

Powell and Lichetenfels (1979)

Life history

$\begin{array}{lll}1 & \mathrm{~m} & \text { hatching-pupation } \\ 2 & \mathrm{~m}, \mathrm{~s} & \text { egg-adult } \\ 3 & \mathrm{~m} & \text { egg-adult }\end{array}$

$\begin{array}{ll}1 & N \\ 1 & N\end{array}$

$\begin{array}{lll}\text { N } & \text { p. } 266 & \text { Sang and Clayton (1957) } \\ \text { N } & \text { p. } 93,95 & \text { Sang (1962) } \\ \text { N } & 8 & \text { Prout (1962) }\end{array}$


Appendix 1 continued

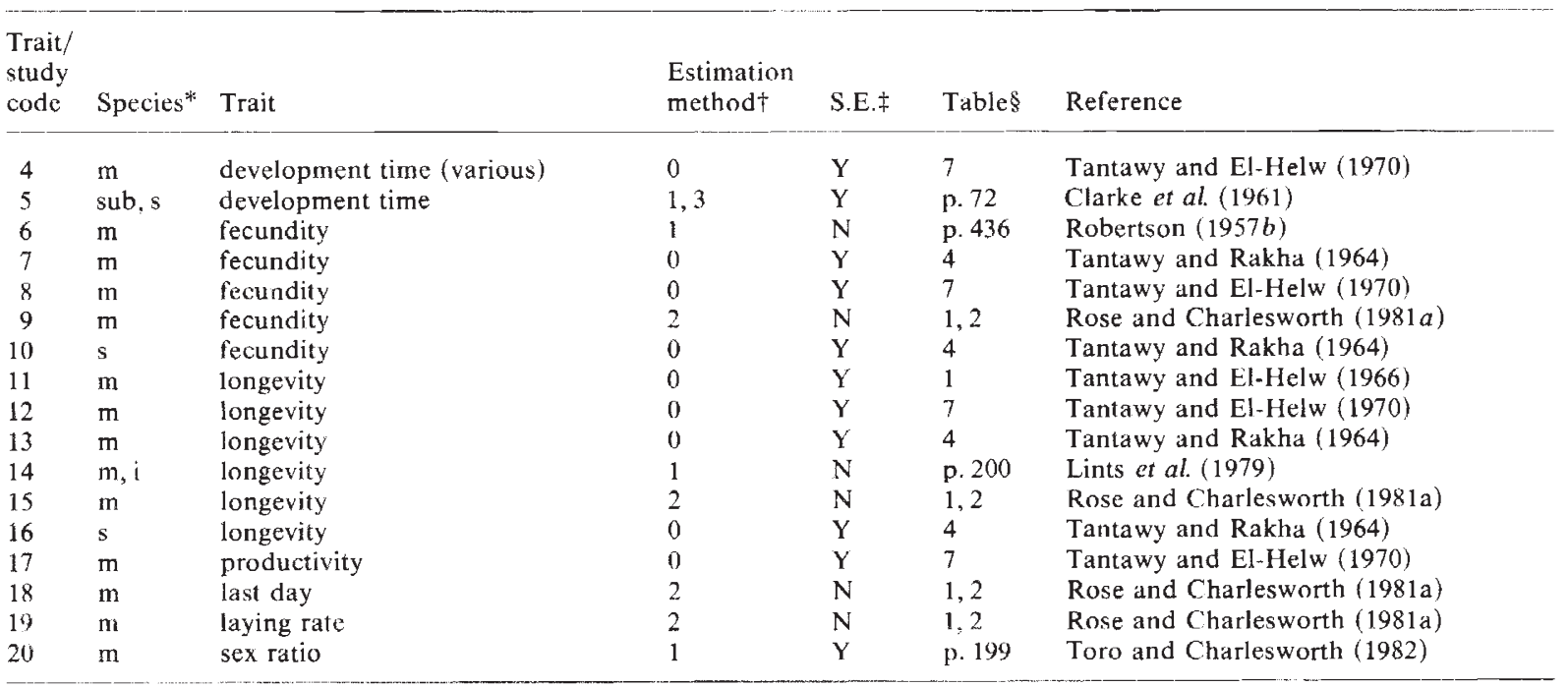

*m, D. melanogaster; s, D. simulans; p, D. pseudoobscura; sub, D. subobscura; pers., D. persimilis; merc, D. mercatorum; a, D. ananassae; mim, D. mimica; ,s, synthetic stock generated by crossing 2 or more strains; i, inbred stock.

$\dagger 0$, offspring on parent regression; 1 , selection; 2 , Miscellaneous methods, principally ANOVA; 3, Half sib analysis; 4, Full sib analysis. ¥Y, at least one $h^{2}$ estimate has an associated SE: these are plotted in Fig. 4 ; N, no S.E. given.

$\S$ Denotes the table or, if prefixed by ' $p$ ', the page from whence the data are drawn. 